\title{
Effect of Different Organic Wastes on the Growth of Black Soldier Fly (Hermetia illucens) Larvae
}

\author{
Firli Azkia Rahmi ${ }^{1}$, Muhammad Yamin ${ }^{2}$, Yorianta Sasaerila ${ }^{1 *}$ \\ ${ }^{1}$ Biology Department, Universitas Al Azhar Indonesia, Faculty of Science and Technology, Jakarta 12110, \\ Indonesia \\ ${ }^{2}$ Research Institute for Ornamental Fish Culture, Ministry of Marine Affairs and Fisheries, Republic of Indonesia, \\ Depok, Jawa Barat 16436, Indonesia \\ *Corresponding author. Email: yshidayat@uai.ac.id
}

\begin{abstract}
Black soldier fly (BSF) is one of the most promising bioconversion agents for organic wastes and potential nutrient-rich food source for the poultry and aquaculture industries. For these purposes, it is essential to produce edible quality larvae of BSF. This study tested the effect of the oil palm dregs (oil palm shreds after the oil is squeezed out), soybean curd residue, and restaurant waste as food on the survival and growth of BSF larvae. About 25 BSF larvae age of six to seven-days-old were placed on each treatment substrates (oil palm dregs, soybean curd residue, and restaurant waste). At 5, 12, and 19 days after treatments were started, all larvae on each treatment were collected for measurements. Results after 19 days showed that the restaurant waste, a mixture of food from West Sumatran food restaurants (RM Padang) and Javanese food restaurants (RM Tegal), produced significantly $(\mathrm{P}<0.05)$ longer body length and width, along with heavier body weight compared to the larvae fed with the other two treatments.
\end{abstract}

Keywords: black soldier fly larvae, BSF, oil palm dregs, soybean curd residue, restaurant waste

\section{INTRODUCTION}

In many cities and municipalities, decision-makers are facing a severe challenge in the management of accumulated daily solid wastes. In Indonesia, about 175.000 tons of solid wastes are generated daily, which is about 64 million tons per annum [1]. The accumulation of these wastes is due to large population in cities/municipalities, and lack of technology to process these wastes [2]. Furthermore, the failure to manage waste causes significant negative consequences, including massive environmental pollution of land as well as marine bodies which has caught global attention, for example, the accumulated plastic wastes in Bali and the polluted Citarum River, West Java [3, 4]. The health issue is another impact of solid waste pollution and needs serious actions that have an immediate effect on addressing the problem $[5,6]$.

Wastes could be divided into two groups; inorganic and organic wastes. Among the 64 MT/annum of wastes, about $40 \%$ are inorganic wastes consisting of $\sim 15 \%$ plastic, $\sim 10 \%$ paper, and $\sim 15 \%$ metals, glasses, clothes, etc. The rest or about $60 \%$ of the wastes are organic wastes [1]. Unlike inorganic waste, organic waste contains a high amount of food and nutrition available to many decomposing organisms, including insects, fungus, and bacteria. Many studies found that the end products of decomposition processes by these organisms could be beneficial for humans [7]. The use of black soldier fly (Hermetia illucens, BSF) to manage organic solid wastes was introduced in the 1990s, and since then has been getting increased attention until today [8].

The use of BSF larvae to manage waste has significant advantages over other methods. This method uses simple and affordable technology with faster and more reliable results that make it suitable for low to middle-income countries [9]. Another approach to this is the decomposition by bacteria, which needs higher cost in technology to operate and to maintain. This particular technique suffers from significant draw-back in the implementation front in different countries due to budget issues. The BSF larvae are found to be efficient in suppressing Drosophila melanogaster, which minimizes the development of bacteria, and reduces health threat to humans along with the better odour of the waste materials [10]. Another benefit is that BSF can colonize and consume a wide variety of resources, ranging from cow manure, animal carcasses, and even human to animal feces [11], which indicate that the BSF can be used to manage a variety of organic wastes. Besides, the residue of BSF larvae is used for organic fertilizer, and the larvae themselves are used as an animal feeder, for example, for fish in aquaculture, or chicken in the poultry industry. As a food source, indeed, the quality of larvae is essential to the animal fed with it, and many studies were reported that the quality of food affects the quality of larvae produced [6].

There are three solid organic wastes produced daily in higher volumes in Indonesia: soybean curd residue, oil palm dregs, and restaurant food wastes. 
Soybean curd residue contains about $23-24 \%$ protein and about $4.6 \%$ fat, are generally used as animal feed for pig, cow, etc. The oil palm dregs (oil palm shreds after the oil is squeezed out) contains about $15.9 \%$ protein and $7.8 \%$ fat [12]. Organic food waste from the restaurants includes a variety of proteins and fat types that are beneficial for the larvae. Due to the continuous generation of these three solid wastes in high volume in Indonesia, this experiment was designed to test whether BSL larvae can be used to decompose these wastes.

\subsection{Materials and Methods}

\subsubsection{Research location and materials}

This experiment was carried out at the laboratory of the Research Institute for Ornamental Fish Culture (BRBIH), Ministry of Marine Affairs and Fisheries of the Republic of Indonesia. Materials used in this experiment were a plastic container $(40 \mathrm{~cm} \times 30 \mathrm{~cm} \times 10 \mathrm{~cm})$ to house the flies attractant, wooden shelf where the plastic container containing fly attractant was placed, black plastic bowl (diam. $20 \mathrm{~cm}$ ) to be filled with food substrates and where the BSF larvae were cultivated during bioconversion process. A digital camera was used for the documentation, while digital scale and digital caliper were used to measure the larvae dimensions. BRBIH provided oil palm dregs and soybean curd residue, and restaurant food waste was collected from 10 restaurants, a mixture of Javanese food restaurants (RM Tegal/ Warteg) and West Sumatran food restaurant (RM Padang).

The black soldier fly colony used in this experiment has been reared in BRBIH facility for several generations. The media in which BSF females oviposit their eggs were in the form of porridge. The porridge was prepared from a mixture of palm oil residue, coconut dregs, oil palm dregs, soybean curd residue, and water. The prepared blend was kept fermenting for 2-3 days. After three days, about $2 \mathrm{~kg}$ of the fermented material was poured into the $40 \mathrm{~cm} \times 30 \mathrm{~cm}$ plastic containers. Female BSF was attracted to the prepared material for oviposition on the surface of the substrate. Several wooden sticks $(2 \mathrm{~cm} \times 2 \mathrm{~cm} \times 15 \mathrm{~cm})$ were placed on the top of the container as oviposition sites. Eggs laid by BSF female (about 300 eggs) on the surface of the wooden sticks were collected using a bamboo stick. The collected eggs were placed in a petri dish containing a weighing paper. Eggs were weighted with a digital scale, and about $1 \mathrm{~g}$ of eggs was sowed on the surface of the prepared media (treatments).

\subsubsection{Experimental Set-Up}

The treatments were different types of food for BSF larvae: 1) oil palm dregs (4 kg), soybean curd residue (4 kg), and 3 ) shredded restaurant solid organic wastes $4(\mathrm{~kg})$. The soybean curd residue and oil palm dregs were prepared by breaking them into small pieces by hand. Each substrate was mixed thoroughly using a small shovel and metal spoon to reach target homogeneity and then poured into the plastic bowl. For restaurant organic waste, buckets of solid waste from the restaurant were separated from inorganic waste, if present. The final prepared treatment media were placed in each designated bowl. There was no repetition of food treatment. The BSF larvae with the age of 6-7 d old were placed on each surface of the treated substrate. The number of larvae that were placed on the substrate was about 25 larvae and weighs about $1 \mathrm{~g}$ (larvae were collected and weighed). The size of all larvae was measured with a digital calliper before placing them on each treatment substrate. At the 5,12, and $19 \mathrm{~d}$ after treatment began, all larvae on each substrate treatment were collected for measurements. To imitate field conditions, the substrate in each treatment during this experiment was left as it was without additional treatment to the substrate, including watering, until the experiment completed. Statistical analysis for this experiment used one-way analysis of variance (ANOVA) followed by Tukey's HSD test to analyse differences between treatments $(\mathrm{P}<0.05)$.

\subsection{Our Contribution}

This paper presents additional information about the ability of organic waste such as oil palm dregs, soybean curd residue, and restaurant waste to be used as feed media for BSF larvae. The results show that the administration of all three types of waste can influence the growth of BSF larvae, so the use of BSF larvae as a waste reduction can be applied and able to overcome the problems caused by organic waste

\subsection{Paper Structure}

This paper is organized as follows. Section 1 introduces the introduction in this paper, which reviews the background and purpose of the observations. Section 2 . Then, the results and discussion of observations are in Section 3. Finally, Section 4 discusses the paper and provides suggestions for further research.

\section{RESULTS AND DISCUSSION}

\subsection{Physiochemical Characteristics of the Treatment Substrates}

The characteristics of each food treatment used in this experiment are presented in Table 1. Restaurant wastes had the highest temperature among the three food treatments. The highest humidity found in Soybean curd treatment. 
Table 1 Characteristics of Soybean curd residue, Oil palm dregs, and Restaurant solid organic wastes

\begin{tabular}{|c|c|c|c|}
\hline \multirow[b]{2}{*}{ Parameters } & \multicolumn{3}{|c|}{ Treatment } \\
\hline & Soybean curd residue & Oil palm dregs & $\begin{array}{c}\text { Restaurant solid organic } \\
\text { wastes }\end{array}$ \\
\hline Temperature & $26.7-28.9^{\circ} \mathrm{C}$ & $27.4-28.8^{\circ} \mathrm{C}$ & $30-36^{\circ} \mathrm{C}$ \\
\hline $\mathrm{pH}$ & $4-7$ & 7 & 6 \\
\hline Humidity & $70-90 \%$ & $70 \%$ & $70 \%$ \\
\hline Texture & $\begin{array}{l}\text { Wet from the beginning } \\
\text { to the end of the } \\
\text { experiment }\end{array}$ & $\begin{array}{l}\text { Dry from the beginning } \\
\text { to the end of the } \\
\text { experiment }\end{array}$ & $\begin{array}{c}\text { Wet in the beginning, drier } \\
\text { at the end of the } \\
\text { experiment }\end{array}$ \\
\hline Colour & $\begin{array}{l}\text { White in the beginning, } \\
\text { turned brown at the end }\end{array}$ & $\begin{array}{l}\text { Brown in the beginning, } \\
\text { turned black at the end }\end{array}$ & $\begin{array}{l}\text { White, green, and red in } \\
\text { the beginning, turned } \\
\text { brown at the end }\end{array}$ \\
\hline Size of particle & Fine & Small to fine & Large \\
\hline Odour & $\begin{array}{c}\text { Sour in the beginning, } \\
\text { getting stronger at the end } \\
\text { of the experiment }\end{array}$ & $\begin{array}{c}\text { Slightly sour in the } \\
\text { beginning, getting less } \\
\text { sour, becoming odourless } \\
\text { at the end of the } \\
\text { experiment }\end{array}$ & $\begin{array}{l}\text { Slightly sour in the } \\
\text { beginning, becoming less } \\
\text { sour at the end of the } \\
\text { experiment }\end{array}$ \\
\hline
\end{tabular}

\subsection{Effect of Food Treatments to BSF Larval Growth}

Larvae of BSF were found to be capable of living and decomposing all three kinds of food (oil palm dregs, soybean curd residue, and restaurant waste) used in this experiment, which means that these wastes can be managed by using the larvae of BSF.

Food types have a significant effect $(\mathrm{P}<0.05)$ to growth parameters of BSF larvae (Table 2). The longest larval body length and width were observed on larvae fed with restaurant waste followed by soybean curd residue-fed larvae (Table 2). The highest total larval body weight is observed in restaurant waste fed larvae $(34.77 \mathrm{~g})$, followed by oil palm dregs fed larvae $(29.84 \mathrm{~g})$ and soybean curd residue fed larvae (4.82 g) (Table 2).

These results were consistent with previous research, which found protein as the most crucial macronutrient needed by insect larvae [13]. Among the three food treatments used in this experiment, restaurant wastes had the highest protein content at $39 \%$ [6], followed by soybean curd residue at 23\% [14], and oil palm dregs at 16\% [10] Besides, restaurant wastes may have a better attraction to larvae due to the various food components it contained, such as meat, fruit, vegetable, fish, etc.

Low total larval weight of larvae fed on the soybean curd residue may be caused by the high mortality of BSF larvae on this substrate treatment as a result of the high moisture content of the substrate. The high moisture content of the soybean curd residue induced nutrient dilution and provided a favourable condition for pathogenic bacteria that may have caused higher larval mortality in this treatment compared to the other two treatments $[15,16]$.

\section{CONCLUSION}

This research has shown the potential of black soldier fly larvae as bioconversion agents of these three wastes that are produced daily in high volume in Indonesia. Higher and variety of protein, fat, and another nutrition source in restaurant solid organic waste could be the determining

Table 2 Average larval length, width, and total larval weight on Soybean curd residue, Oil palm dregs, and Restaurant wastes

\begin{tabular}{|l|c|c|c|c|}
\hline \multirow{2}{*}{ Parameters } & \multirow{2}{*}{ Unit } & \multicolumn{2}{|c|}{ Treatment } & \multirow{2}{*}{ Restaurant wastes } \\
\cline { 3 - 5 } & & $\begin{array}{c}\text { Soybean curd } \\
\text { Residue }\end{array}$ & Oil palm dregs & $23.04 \pm 0.19^{\mathrm{a}}$ \\
\hline Length $(\mathrm{n}=12)$ & $\mathrm{mm}$ & $20.51 \pm 0.21^{\mathrm{c}}$ & $21.38 \pm 0.26^{\mathrm{b}}$ & $5.46 \pm 0.07^{\mathrm{a}}$ \\
\hline Width $(\mathrm{n}=12)$ & $\mathrm{mm}$ & $4.88 \pm 0.06^{\mathrm{b}}$ & $5.11 \pm 0.10^{\mathrm{b}}$ & 34.77 \\
\hline Total weight* & $\mathrm{g}$ & 4.82 & 29.84 & \\
\hline
\end{tabular}

*Total weight of BSF larvae on each treatment substrate at day 19. Low body weight indicates low larval survival rates in the treatment. Means \pm SE with different letters are significantly different statistically $(\mathrm{p}<.05)$ 
Effects of feedstock on larval development and process efficiency in waste treatment with black soldier fly (Hermetia illucens), J. Clean. Prod. 208 (2019) 211-219. https://doi.org/10.1016/j.jclepro.2018.10.017

\section{ACKNOWLEDGMENT}

We would like to thank the Research Institute for Ornamental Fish Culture (BRBIH), Ministry of Marine Affairs and Fisheries of the Republic of Indonesia for providing laboratory and BSF cultures for this research.

\section{REFERENCES}

[1] KLHK (Kementerian Lingkungan Hidup dan Kehutanan Republik Indonesia), IndonesiaFinlandia bahas kerjasama pengelolaan sampah menjadi energi, 2017, http://www.menlhk.go.id/site/single_post/175

[2] S. Kumar, S.R. Smith, G. Fowler, C. Velis, S. J. Kumar, S. Arya, R, Kumar, C. Cheeseman, Challenges and opportunities associated with waste management in India, The Royal Society (2017) 111. DOI: https://doi.org/10.1098/rsos.160764

[3] National Geographic, A, T. Siddharta, Bali fights for its beautiful beaches by rethinking waste, plastic trash, National Geographic, 2019, https:// www. National geographic.com/ science/ 2019/10/bali-fights-for-its-beautiful-beaches-byrethinking-waste-plastic-trash/

[4] D. Tarahita, M.Z, Rakhmat, Indonesia's Citarum: the world's most polluted river, The Diplomat, 2018, https://thediplomat.com/2018/04/indonesiascitarum-the-worlds-most-polluted-river/

[5] S. Rathi, Alternative Approach for Better Municipal Solid Waste Management in Mumbai India. Journal of Waste Management 26(10) (2006) 1192-1200. DOI: https://doi.org/10.1016/ j.wasman. 2005.09 .006

[6] UN-Habitat, Solid Waste Management In Cities Kenya: United Nations Human Settlements Program, 2018.

[7] D. Sarpong, S. Oduro-Kwarteng, S. F. Gyasi, R. Buamah, E. Donkor, E. Awuah, M.K. Baah, Biodegradation by composting of municipal organic solid waste into organic fertilizer using the black soldier fly (Hermetia illucens) (Diptera: Stratiomyidae) larvae, Int. J. Recycl. Org. Waste Agric (2019) 1-10. DOI: https://doi.org/10.1007/s 40093-019-0268-4

[8] C. Lalander, S. Diener, C. Zurbrugg, B. Vinneras,
[9] L.A. Guerrero, G. Maas, W. Hogland, Solid Waste Management Challenges for Cities in Developing Countries, J. Waste Manag. 33 (1) (2013) 220-232. DOI:

https://doi.org/10.1016/j.wasman.2012.09.008

[10] S. W. Bradley, D. Sheppard, Housefly Oviposition Inhibition by Larvae of Hermetia illucens the Black Soldier Fly, J. Chem. Ecol. 10 (6) (1984) 853-859. DOI: https://doi.org/10.1007/ BF00987968

[11] A. J. Charlton A, M. Dickinson, M.E. Wakefield, E. Fitches, M. Kenis, R. Han, F. Zhu, N. Kone, M. Grant, E. Devic, G. Bruggeman, R. Prior, R. Smith, Exploring the chemical safety of fly larvae as a source of protein for animal feed, J. Insects as Food Feed. $1 \quad$ (1) (2015) 7-11. DOI: https://doi.org/10.3920/JIFF2014. 0020

[12] Rachmawati, B. Damayanti, P. Hidayat, S. Hem, M.R. Fahmi, Perkembangan dan Kandungan Nutrisi Larva Hermetia illucens (Linnaeus) (Diptera: Stratiomyidae) pada Bungkil Kelapa Sawit, JEI 7 (1) (2010) 28-34. DOI: https://doi.org/10.5994/ jei.7.1.28

[13] M. Gold, J.K. Tomberlin, S. Diener, C. Zurbrügg, A. Mathys, Decomposition of Biowaste Macronutrients, Microbes, and Chemicals In Black Soldier Fly Larval Treatment: A Review, J. Waste Manag. (2018) 302-318. DOI: https://doi.org/ 10.1016/j.wasman.2018.10.022

[14] M.A. Tifani, S. Kumalaningsih, A. F. Mulyadi, Produksi Bahan Pakan Ternak Dari Ampas Tahu Dengan Fermentasi Menggunakan EM4 (Kajian pH Awal dan Lama Waktu Fermentasi), Malang: Fakultas Teknologi Pertanian-Universitas Brawijaya, 2015

[15] B. Dortmans, S. Diener, B. Verstappen, C. Zurbrugg, Black Soldier Fly Biowaste Processing: A Step-By-Step Guide Dubendorf, Switzerland: Swiss Federal Institute of Aquatic Science and Technology, 2017

[16] R. Suciati, H. Faruq, Efektifitas Media Pertumbuhan Maggot Hermentia illucens (Lalat Tentara Hitam) Sebagai Solusi Pemanfaatan Sampah Organik, BIOSFER, J. Bio. Pend..Bio, 2 (1) (2017) 8-13 